\title{
From Japanese Soldiers to Chinese Rebels: Colonial Hegemony, War Experience, and Spontaneous Remobilization during the 1947 Taiwanese Rebellion
}

\section{VICTOR LOUZON}

A former part of the Qing Empire, Taiwan was colonized by Japan in 1895 and returned to China, upon Tokyo's defeat, in 1945. Two years later, a revolt broke out against the mainland Chinese authorities and was brutally crushed. This episode, known as the February 28 Incident, has been at the center of memory wars in Taiwan since democratization. Historical accounts have tended to focus on the background causes of the Incident and on the role played by the Taiwanese elite. This article argues that devoting more attention to grassroots participants and their repertoire of action can shed new light on the events. During World War II, many young Taiwanese were mobilized in the Japanese army and paramilitary structures. This experience persisted in collective memory after Japan's defeat. During the revolt, young Taiwanese spontaneously "remobilized" the repertoire of actions and symbols formed during the war, with important consequences.

Keywords: aftermath of war, colonialism, demobilization, February 28 Incident, Japanese wartime empire, post-colonialism, rebellion, second Sino-Japanese war, Taiwan

N September 27, 2014, Ma Ying-jeou, then president of the Republic of China (Taiwan), was hit by an object thrown by a student activist during a reception. The student was angered by Ma's policy of rapprochement with mainland China, which he deemed dangerous for the democratic island. Little harm was caused: the missile was a book called Formosa Betrayed, a famous account by American diplomat George Kerr of the "February 28 Incident." The "February 28 (or 2.28) Incident" is the conventional expression for the short 1947 Taiwanese revolt against Chinese Kuomintang authorities who had regained sovereignty over Taiwan in 1945, after fifty years of Japanese colonial rule (1895-1945). Triggered by the accidental killing of a man by the police in Taipei, the movement quickly spread to the cities and towns of the entire island, facing little resistance from the surprised and understaffed police and military. Administrator Chen Yi and his government were paralyzed for ten days before reinforcements began to arrive from the mainland on March 9. In March and April, the troops engaged in a bloody "pacification" campaign that killed thousands of Taiwanese, ${ }^{1}$ a vast majority of whom were noncombatants. A few dozen mainland Chinese (civilian and military) also lost their lives.

Victor Louzon (v12385@columbia.edu) is INTERACT Postdoctoral Scholar at the Weatherhead East Asian Institute, Columbia University, and Research Associate at the Center for History, Sciences Po (Paris).

${ }^{1}$ It is probably safe to keep in mind the estimate of 10,000 dead chosen by Phillips (2003). 
As the activist's choice of weapon shows, the Incident is still a hot topic, since it pertains to the legitimacy of Chinese sovereignty on the island. Its interpretation is thus highly contentious in the political competition between those who favor independence and those who support rapprochement, if not unification, with the People's Republic of China (PRC). Any discussion of the 1947 tragedy was proscribed by the Kuomintang regime until it liberalized at the end of the 1980s. Since then, a vast amount of scholarship has been devoted to it.

Research on the Incident has focused on two sets of issues: establishing the facts and attributing responsibility for the bloodshed, and identifying the causes of the uprising. The Taiwanese had many grounds to be disgruntled in 1946-47. The Japanese war effort drained the resources of the island. When the Republic of China took over, the hardships of reconstruction (such as inflation and unemployment) were compounded by carpet-bagging, corruption, and inefficient economic policies. Authoritarianism prevailed over demands for constitutional rule. Among Taiwan's new rulers, the island's past as a Japanese colony prompted cultural contempt and a tendency to discard any criticism as ungratefulness (Chen Tsui-Lien 2002; Lai 1994; Lai, Myers, and Wei 1991; Phillips 2003). The Kuomintang administration failed to uphold the standards of harsh but efficient governance set by the Japanese, the hopes raised by the end of colonial rule were frustrated, and the population was deeply antagonized. Given this state of affairs, an accidental spark-one too many instances of police brutality-was enough to set the island on fire.

The aforementioned, however, only explain the causes for discontent, not the way most Taiwanese rebels expressed their frustration. This latter point has received little attention because existing research, although rich in quantity and quality, is unbalanced in favor of one type of protagonist (and victim) of the February 28 Incident: the Taiwanese elite, who organized “Resolution Committees” (chuli weiyuanhui 處理委員會), put forward demands for political reform and local autonomy, and were particularly targeted by the secret police afterwards. Their agenda and methods were largely nonviolent. However, they were dependent, for leverage during negotiations with the authorities, on a much larger group whose means were less peaceful: tens of thousands of young men who took to the streets, besieged official buildings, plundered police stations and arsenals, and sometimes attacked mainland Chinese civilians and even soldiers. These initiatives, over which the elite had almost no control, were what the Incident was made of at the grassroots level. ${ }^{2}$

This article focuses on these young Taiwanese rebels and their repertoire of action. It proposes that the revolt was an instance of spontaneous remobilization. Mobilization for total war under Japanese rule provided young Taiwanese with practical and symbolic resources that were then remobilized in the postcolonial context of 1947 and served to inform the rebels' actions during the uprising.

This does not mean that the insurgents supported Japan or "felt" Japanese, and thus refused Chinese sovereignty, as it has sometimes been maintained. Indeed, in 1947, while the Kuomintang authorities (falsely) blamed the Communists for triggering the unrest,

${ }^{2}$ The Chinese Control Yuan estimated the number of rebels at 50,000-60,000, thousands of whom actually participated in direct clashes with the army or police (NSHA 280-84). 
they held that its overriding cause was the “remaining poison” (yidu 遺毒) of Japanese colonialism, which had estranged Formosans from their mainland compatriots. After 1949, this reading of the events was somewhat silenced, Japan now being an ally in the Cold War, and the Communists took all the blame. It has, however, resurfaced since the 2000s, concurrent with the rising nationalist tensions in East Asia, the opposition in Taiwan between supporters of independence and unification, and the frustration among the latter (both in Taiwan and the PRC) over the "Japan complex" (Riben qingjie 日本情節) of the Taiwanese, purportedly infatuated with their former colonial masters (e.g., Chi 2007).

This interpretation, however, is incorrect. First, the 1945 retrocession had been warmly welcomed by the Taiwanese population as a whole. Second, the rebels produced almost no discourse on national allegiance, whether in favor of Taiwanese independence or of Japan. In the case of these young rebels, as this article will show, "Japaneseness" is best understood not as a national identity but as a repertoire of behaviors, symbols, and discourses that they mobilized in the course of the rebellion. Moreover, this repertoire cannot be described solely as Japanese: it stemmed from the specific experience of World War II. Most of those who took part in violent rebellion were young males born in the late 1910s and 1920s. During the war, therefore, they were old enough to fight or to attend middle or high school. In 1947, they were in their twenties or late teens and constituted a generation bound together by the commonality of its historical experience, where the war figured prominently.

The mobilization and militarization of Taiwanese society during World War II transformed Japanese colonial hegemony. ${ }^{3}$ All hegemonic projects rely on the participation of materially and symbolically incentivized groups (in this case, mobilized young men) and therefore have "effects of subjectivation" (Bayart 2008), shaping "the way in which individuals are urged to constitute themselves as subjects, ... the models proposed [to them]" (Foucault [1984] 1990, 29). These effects did not end with Japan's defeat, for in some ways the troubled aftermath of World War II in Taiwan prolonged the militarization of society while fostering frustration and humiliation among demobilized youth. In 1947, they actively participated in the revolt, spontaneously remobilizing the "Japanese-military repertoire" developed during the war. ${ }^{4}$

\footnotetext{
${ }^{3}$ Hegemony is understood here in the Gramscian sense: the ability of a ruling group to present its interests and values as common sense and beneficial to society as a whole, thus exerting power through consent and not only through domination (Forgacs and Hobsbawm 2000, 205-6).

${ }^{4}$ Young rebels produced few written sources, a dearth partially compensated for by numerous interviews with survivors, collected and published in the 1990s by Taiwanese historians. From this material, we can expect neither accuracy about time and place, nor a faithful account of the ideological atmosphere in 1947. Individual memories are bound to be reframed by subsequent historical developments, to which we must be attentive to avoid the pitfall of reconstruction. However, if used with care, in large numbers and jointly with written sources, oral histories offer a wealth of practical details that go unrecorded by official archives and, being considered insignificant by the interviewees themselves, are less likely to be distorted by superimposed narratives (Descamps 2001, 451-504). To distinguish oral history from other sources, the year in which the interview was conducted is indicated in square brackets in the reference.
} 


\section{A New Colonial Hegemony: Japanization as Militarization in Wartime Taiwan}

Enrollment of Taiwanese troops in World War II happened late: the Japanese were wary of arming colonial subjects and feared some would side with their former Chinese compatriots. Nevertheless, the Japanese needed manpower and, in those southeastern regions of China that shared common dialects with Taiwan, could use Formosans as middlemen. Taiwan was thus progressively subjected to mass mobilization. In 1937, the Japanese Government-General (sōtokufu 総督府) started hiring Taiwanese porters (gunpu 軍夫) to carry out diverse tasks on the mainland, later renamed “auxiliaries" (gunzoku 軍属). They were often sent to China, Southeast Asia, and the Pacific to carry military supplies, serve as interpreters, guard prisoners of war (POWs), maintain local order, etc. Recruitment of volunteer soldiers began in February 1942 in the Army, and in August 1943 in the Navy. The Japanese eventually resigned themselves to conscription in Taiwan in January 1945, in order to defend the island against a potential American invasion (Kondō 1996, 351-53; Ts'ai 2009, 181).

The experience of the Taiwanese in the Japanese military was short but widespread. Out of a total population of 6.5 million, some 207,000 young men served as soldiers or auxiliaries - a large number considering that the male population between the ages of seventeen and thirty was estimated at 630,000 in 1940 (Lin 1996, 225). Thirty thousand of these men ( 15 percent) died in service. Given that many were supposed to be noncombatant personnel, this is an impressive proportion. It is worthy of note, however, that the line between combat and noncombat duties was blurry: “auxiliaries” like Li Qingbo, who was recruited as an interpreter, were often asked to perform police or even combat missions in occupied areas (Chou 1997, 35 [1995]).

The volunteering system implemented between 1942 and 1944 relied in part on coercion. Many Taiwanese were forced to enlist and became "pawns of empire" (Kushner 2010). Others were cornered or pressured into volunteering. Hong Canrong enrolled to keep his mother-who was at risk of being jailed after committing an infraction-out of trouble. Lu Yongfa, then a teacher, was publicly challenged by a Japanese officer to put into practice the ideas of patriotism and sacrifice he was paid to exalt in class (Chou 1997, 116, 146).

Nevertheless, the authorities were overwhelmed by the number of applicants: during the first wave of volunteering, over 425,000 persons applied for 1,000 positions (Chou 1996). The high application rate was certainly encouraged by the Government-General, but it also stemmed from a sincere desire within a section of the population. Many volunteers, who wanted to make a show of loyalty, signed their application with their own blood (Ts'ai 2008, 107 [1996], 327 [1995], 351 [1996]). This imitation of a Japanese model does not prove that mobilization was without constraint, but it does suggest that it was associated with bravery and sacrifice.

It is hardly surprising that Japanese propaganda presented soldiering to the population of Formosa as a glorious privilege, and not as servitude. More notable is the fact that this cliché took on a concrete meaning for the Taiwanese. The status of soldier being originally reserved for Japanese nationals alone, extending it to the colonized was a symbolic gesture of integration. As Takashi Fujitani $(2011,47-48)$ has argued in the case of Korea, the unintended consequences of Japan's new inclusive wartime discourse mattered more than its dubious sincerity. The intense competitiveness of volunteering also had more 
personal implications, as it made joining the army a proof of individual worth. Even the former soldier Wu Shen'an, who asserted when interviewed that he "wasn't actually a volunteer," remembered with some pride that "the good ones joined the soldiers of first category, the other ones joined the reserve force." The word youxiu 優秀 (good, excellent) was commonly used in ulterior oral testimonies to describe the qualities, both moral and physical, of those who became soldiers (Chou 1997, 114 [1995]; Ts'ai 2008, 34 [1995], 73 [1995]). There was an "objective" dimension to this assessment, since volunteers had to take written, oral, and physical examinations to be accepted. Success at these tests occupies a strikingly important place in the witnesses' recollections (whereas life in the army itself is often recalled as brutal and humiliating). One veteran recollected that "you had to take a physical test to become a soldier... So people more or less thought 'if such and such person does not become a soldier, it means he is useless' (mei you yong 沒有用)” (Ts’ai 2008, 327 [1995]).

The glory of joining the army was materialized in a series of rites of passage. The first ritual consisted of receiving the mobilization order:

The policemen wore white gloves and [showed] the utmost reverence. When approaching the house of the [soldier] who was about to leave, he saluted and announced his arrival. The person receiving the order walked out, all dressed up, and took it. [Then], the policeman shouted 'Congratulations!', bent over a second time and left. (Ts'ai 2008, 108 [1996])

To measure the importance of such a ceremony, we have to bear in mind that the Japanese colonial empire was largely controlled by the police. To the ordinary Taiwanese, the policeman—bitterly referred to as "Lord Police" (keisatsu daijin 警察大人)—“personified the world of order and law" (Ts'ai 2009, 67). For a limited time and place, enrollment led to a reversal of colonial hierarchies. "Most people thought that being a soldier sent to the frontline was like giving your life to the country, whereas the police were just maintaining order behind the lines. So people thought soldiers were bigger than policemen (bing bi xuncha da 兵比巡查大)" (Ts'ai 2008, 108 [1996]).

The recruit went through a second ritual when he bade farewell to civilian life and left for the training center. The local community was associated with the departure, which was a collective ceremony, integrating the recruit with his new peer group. When Jian Chuanzhi left his village with other volunteers in 1942,

... the county office mobilized the students, the youth league, all the population and officials [of the village] to escort us to the station. Everybody was holding little flags, with our five names written on them, and everyone was shouting in unison 'Banzai! Banzai!'. It was very intense. So when I finally entered the training center and it became tough, all I had to do was remember the way we had been seen off. It was enough to reject any idea of fleeing back home. Really, doing this would have been too much of a loss of face (tai mei you mianzi 太没有面子). (Ts'ai 2008, 80 [1995])

For the conscripts of 1945, the rituals were not as numerous and solemn as those that the volunteers had gone through. However, conscription still implied an array of 
examinations. If the system was similar to the Korean one, which is plausible, enrollment was accompanied by instruction delivered before training: soldiering required skills and a measure of education, particularly in the Japanese language (Fujitani 2011, 274-78).

Thus, in oral histories, enlistment is almost always described as empowering. Although Formosans were rarely promoted above the rank of lance corporals (heicho 兵長) (Ts'ai 2008, 86 [1995]), the simple fact of having a rank meant the soldier entered the "official" world of the colonizer. It was also an enduring source of local prestige, materialized in coveted objects like the uniform or the sword (guntō 軍刀)—a weapon usually restricted to sergeants and more senior officers (Chou 1997, 114 [1995]).

For Taiwanese youth, the war also entailed upward mobility. A soldier's pay was relatively good, and since the army first tapped into Taiwan's Japanese population $(400,000$ persons in late 1943), enlistment of young Japanese created a vacuum that opened career opportunities at home and abroad. Sometimes, deployment overseas even allowed the Taiwanese to become the sub-imperial overlords of foreign populations. Zheng Chunhe, who was sent to Timor, was in contact with "natives" (turen 土人) on a daily basis. Far from feeling sympathy for them, Zheng finally understood what it was like to be Japanese in Taiwan:

I understood for the first time why the Japanese despised the Taiwanese. We didn't have the same customs, life standards were very different, we couldn't communicate.... Same thing, when I was in Indonesia, I had the feeling that local indigenes were not like the Taiwanese. It was really hard to respect those people from the bottom of one's heart (da cong xin di jiyu zunzhong 打從心底給予尊重). (Ts'ai 2008, 58 [1997])

Even less measurable, but equally important, was a form of revirilization. Japanese imperialism had appropriated Orientalist clichés depicting Asian populations as effeminate (memeshii 女々しい) and needing to be “toughened up” (Mark 2003, 609). The war presented many Taiwanese and Koreans "with the opportunity to restore their masculinity" by becoming martial subjects of the Emperor (Fujitani 2000, 134). In several Taiwanese localities, members of female youth groups made public vows to marry only men who volunteered to enlist in the army (Chatani 2014, 235).

Mobilization in the war effort was always associated with a degree of cultural assimilation. Enlistment often resulted in the adoption of a Japanese name (kai seimei 改姓名), which allowed the soldiers to blend in better. Indeed, the Imperial Army prided itself on not enforcing "colonial" separation between races, and hence the Taiwanese were generally scattered in Japanese units. Taiwanese soldiers felt some pressure to change names, and it was easier to "go with the flow" (Ts'ai 2008, 53 [1997]), but the ultimate decision was based on free choice. As such, it symbolized a subjective transformation: a soldier chose at the same time a Japanese name and a nom de guerre. Liu Delu renamed himself Takeyama Katsuo 武山勝雄, a name in which three characters out of four conveyed the idea of martial valor (Chou 1997, 14 [1995]). Zheng Chunhe recalled: "I always wanted to have the upper hand and be upright as a cedar tree in my actions, so I chose Uesugi 上杉 (杉 = cedar) as my last name. And I chose Shigeo 重雄 (雄 $=$ hero) as my first name. Let’s say that it was what I expected from myself” (Ts'ai 2008, 53 [1997]). 
The kai seimei policy was part of the larger Kominka ("imperialization”) movement. Launched in 1937, it was a campaign of rapid and mostly coercive acculturation directed at Taiwan's Chinese cultural roots (Chou 1996, 58). Notably, this campaign was not separable from the militarization of society, understood as the diffusion in social life of martial values and military forms of organization. To this extent, inculcating Japanese ways was part of the "spiritual mobilization” (seishin doin 精神動員) of the colony. For a whole generation, Japanese culture was synonymous with a "war culture."5

This process of militarization affected Taiwanese society well beyond the soldiers. It had an impact on all male teenagers and young men. The Kominka primarily targeted younger generations. Since Japan's conquest of Taiwan and first attempts at assimilation (dōka 同化), the category of "youth" was used by the state and by modernization activists to promote values of vigor and progress, as well as encourage a break with the "old" (precolonial) culture (Chatani 2014; Chen Wensong 2015). From 1937 onwards, educational institutions became privileged places for the inculcation of patriotic and militaristic values. State-sponsored paramilitary organizations multiplied, most notably youth leagues (seinendan 青年団), which had been extended to the colonies after proving useful in Japan proper as proxies for state mobilization. The Taiwanese seinendan saw their scale considerably enhanced during World War II (membership approximated 270,000 in 1939), and they became central to mobilization and Japanization efforts. Members, who wore uniforms and performed military drills, were used to help with labor, construction, maintaining order, and spreading the use of Japanese. They became a recruiting pool of auxiliaries and soldiers (Chatani 2014, 23, 207-8).

Many other paramilitary bodies operated at the time. It is estimated that in 1945 state agencies were able to mobilize a daily labor force of 270,000 to 300,000 by tapping into the numerous organizations that crisscrossed Taiwanese society, such as the able-bodied corps (sōteidan 壮丁団) and the defense leagues (bōeidan 防衛団). These groups took up missions such as fighting fires after aerial bombings, or training to defend Taiwan in the event of an American landing (Ts'ai 2009, 162, 229-30). Like the youth leagues, sōteidan and bóeidan served as recruiting pools for the army (Ts'ai 2008, 32 [1995]). The authorities emphasized the analogy between participation in youth organizations and military service. For instance, members of the Taiwan Patriotic Labor Youth Corps, created in March 1940, earned the respected title of military reservists (zaigo gunjin 在郷軍人) when they returned from service (Chatani 2014, 219). Although on a more modest scale than serving as a soldier, joining a paramilitary group was a source of empowerment for a young man. It was a shortcut to a position of relative prestige in a society normally dominated by Japanese and elders. It was also a way of proving one's worth, since leadership positions within these organizations were generally filled through open competition.

Lastly, even the students who did not belong to any such group received basic military training on a regular basis in their schools, which all kept a number of weapons for the purposes of drills. As Benedict Anderson wrote about wartime Java, the experience of

${ }^{5}$ The same transformation happened in other peripheries of the empire like Okinawa, where the 1920 s project of Japanizing and "civilizing" the population was conflated, during the war, with the imposition of military discipline (Tomiyama 2005). I borrow the term "war culture" from Stéphane Audoin-Rouzeau (Audoin-Rouzeau and Becker [2000] 2003). 
militarization spread through "the network of informal relationships between youths in the larger society" - neighbors, friends, relatives, including young boys who "watched their elder brothers with fascination" (Anderson 1972, 30; Kondō 1996, 358).

In short, the extent of militarization far exceeded that of enlistment. It can be said that war mobilization produced a particular form of colonial hegemony: Japanese rule operated "not simply through repressive means, [but also] by producing desires and presenting opportunities to fulfil them" (Fujitani 2000, 134). In Japanese-controlled Taiwan, wartime hegemony was different from prewar hegemony on account of the militaristic norms it conveyed; it was no longer primarily based on the ideals of modernization and civilization, which Japan claimed to embody in Asia (Ching 2001, 110). It also had a broader social base, targeting a larger and younger group than the native elite of the 1920s. War mobilization affected Taiwanese youths from all social backgrounds, providing them with models of behavior and identification — what can be called, following JeanFrançois Bayart ([2004] 2007, 233), a "repertoire of subjectivation." With this repertoire came a measure of social empowerment, a symbolic upgrade in the colonial hierarchy, and an opportunity for revirilization.

\section{Aftermath of War in a Decolonized Taiwan: 1945-47}

Japanese colonial rule collapsed almost overnight with Tokyo's defeat, announced by the Emperor on August 15, 1945. On October 25, Taiwan was officially "liberated" (guangfu 光復) by the Republic of China. The Taiwanese first received the news of the war's end with great relief, for it meant not only a return to peace, but also decolonization. This joy, however, was soon mitigated by grim economic realities and misrule. The new Kuomintang authorities tended to behave as conquerors, siphoning the resources of the island and rejecting pleas for reform. Their heavy-handed policy of "resinicization" alienated the Taiwanese elite, as it amounted to excluding them from most positions of power. Furthermore, widespread corruption did not endear the administration to the Taiwanese public (Chang 2006; Chen Tsui-Lien 2002; Lai 1994; Lai et al. 1991; Phillips 2003).

For the population in general, and the militarized youth in particular, coming out of war proved to be a slow and difficult journey. As research on "aftermaths of wars" in modern Europe has shown, the notion of "postwar" tends to obscure the gradual and complex nature of the transition from war to peace (Cabanes and Piketty 2007, 1), including the return of soldiers and POWs, reversion to a "normal" state of peace, and cultural demobilization (Horne 2009). In 1945-47 Taiwan, social and political conditions made a swift return to peace difficult indeed.

On a practical level, the public order situation prolonged some of the wartime realities. The Government-General had maintained about 15,000 policemen. After it stepped down, Chinese authorities faced a dearth of police personnel. In the seventy days between the Japanese surrender and the Chinese takeover, the remnants of the colonial police registered 200 to 300 cases of assault or plunder, "twenty-four [involving] a crowd of more than one hundred people," a very high level of large-scale action considering past social movements in colonial Taiwan (Fix 2006, 327, 341). The Chinese police force that took over in October 1945 had only 1,000 mainland officers, assisted at first by 4,700 Taiwanese auxiliaries - most of whom had been serving in the colonial police and were quite 
discredited (IMH 228/01/01/020). These meager forces faced serious law-and-order problems due to economic distress and the chaos brought about by the sovereignty transfer.

This troubled situation urged the Taiwanese to take matters into their own hands, and scores of self-defense organizations were formed. This was facilitated by fresh memories of paramilitary mobilization. As Cai Mingchuan recalled:

... as a rule, everyone [who had been part of a paramilitary group] kept in touch, and if anything happened [they] would gather immediately to solve the problem. [Furthermore], during the Japanese period, almost all of us took part in military training for students ..., so after the takeover, every time something happened, it came to a lot of people's minds to take their wooden swords and intervene. (Hsu 1995, 53 [1994])

Despite the presence of "well-intentioned people" in these groups, a police report lamented the "great number of bad elements" who used self-defense "as a pretext to congregate and torment local [society]." Some even took the liberty of collecting taxes.

The Kuomintang administration, proving unable to suppress these groups right away, chose to coopt them. In December 1945, the authorities ordered the integration of all paramilitary groups into brigades of volunteer policemen (yiyong jingchadui 義勇警察 隊), trained and led by local police bureaus. An estimated 4,600 to 7,350 armed men were supposed to be absorbed into these brigades, more than the number of official policemen. The police planned to disarm the rest of paramilitary group members (IMH 228/01/01/020). It is also clear that some Chinese mass organizations, such as the Three People's Principles Youth League (sanminzhuyi qingniantuan 三民主義青年團), were sometimes reappropriating groups inherited from the Japanese period. This continuity was not lost on the inhabitants. In Wu Shen'an's reminiscence, the national government merely "imitated the kind of organization [established by the Japanese] when the takeover took place, by creating self-defense brigades (ziweidui 自衛隊)” (Ts'ai 2008, 32 [1995]).

The police admitted that this cooptation strategy was met with a "lukewarm welcome," because the groups to be absorbed were too big and too "heterogeneous" (probably an allusion to the presence of lawless elements in the militias). The endeavor to disarm the Taiwanese seems to have been more successful. The authorities expressed fears that the Japanese Army had deliberately scattered weapons among the population at the end of the war. In actuality, although isolated cases of plotting may have existed, the last Governor-General Andō Rikichi had no intention of sabotaging the takeover. The Imperial Army and paramilitary groups had nevertheless left weapons on the island, which the authorities took drastic measures to recover. Arms traffickers and anyone found with a gun after April 15, 1946, were theoretically punishable by death. However, although some machine guns and rifles were collected, the vast majority of recovered items were hunting weapons, “mismatched guns” (zase qiang 雜色槍), and bladed weapons-by no means a military arsenal. Clearly, the confiscation of Japanese weapons was also a pretext to disarm militias and the population at large (IMH 228/ 01/01/020) 
Furthermore, the prestige of the trade of war was not easily forgotten. In an undated paper summing up developments in 1946, the American vice-consul George Kerr commented that "when [Kuomintang] officers attempted to introduce a training program at the University and Normal School, they were often jeered from the ranks. Cat calls greeted their attempts to conduct drills among students who had had years of drill work under the Japanese" (GK 003/0002/027). Proud of their military know-how, young Taiwanese seemed inclined to serve, but only if it was to defend their island. One month before the rebellion, Kerr wrote that they expressed "great willingness to enter training for a Taiwan Defense Corps, but ... great reluctance to face duty on the mainland" (GK 003/0005/015).

The return to normalcy was especially difficult for Taiwanese veterans of the Imperial Army. Demobilization is always a trying process that entails an identity shift from soldier to civilian, mourning the dead, and social reinsertion. The "moral economy of recognition" (symbolic gratifications such as medals) can facilitate that process by continuing to acknowledge the soldiers' sacrifices in peacetime (Cabanes and Piketty 2007, 4). Right after the defeat, Taiwanese soldiers had benefited from what was, in the Japanese army, colloquially referred to as the “Potsdam promotion” (Potsudamu shinkyū ポツダム進級), a gain by one rank level. After that, they were dramatically downgraded to POWs, and then to marginalized and frequently unemployed young men, suspected of disloyalty by their new motherland. Often, Taiwanese soldiers did not return from overseas territories before the end of 1946. The largest contingent (20,000 men) was repatriated from Hainan after a whole year of captivity, in particularly dire conditions, under Chinese army surveillance (Tang 2005).

Jian Chuanzhi's return took place in April 1946, after eight months in a POW camp. When the boat arrived at Jilong, he "saw from the deck the desolation wrought by Allied bombings, ${ }^{6}$ and also the tattered uniforms and the archaic equipment of the Chinese ${ }^{7}$ sentries." After being robbed by customs employees, he received a free train ticket home from the Red Cross:

Trains were totally run-down; they didn't even have lamps. I just sat with my comrades in this dark and shaky train, and twenty hours later I ended up in my hometown, Luodong, which I had left three years earlier. When we got off the train, the comrades told one another "we'll meet again!", said goodbye, and everyone went home. I thought about the day we had left [for training], when all the people from the village were shouting 'banzai' from the sides of the road. Now I was like a stray dog. (Ts'ai 2008, 89-90 [1995])

On paper, the retrocession had made Taiwan part of a victorious country, China. But these veterans had fought on the wrong side, and they were hence denied the "gesture of symbolic reintegration [of] marching in arms and in uniforms before gathered civilians," which, as an inverted reenactment of mobilization, usually brings the war to a full circle for soldiers on the winning side (Audoin-Rouzeau and Prochasson 2008, 14).

\footnotetext{
${ }^{6}$ Taiwan was bombed by American forces from October 1944 to June 1945.

${ }^{7}$ Oral histories and documents emanating from the rebels rarely distinguish between "mainlanders" (waishengren 外省人) and “Chinese” (Zhongguoren 中國人).
} 
To them, the way back home was no victors' parade. A possible way out was enrollment in the Chinese army. It appears that several thousand Formosans made this choice, often based on illusory hopes of decent pay and service on the island-many were shipped to the mainland, against their will, to take part in the civil war (Xu 1995).

Taiwanese veterans were also denied an honorable defeat. Postwar society no longer shared a "language community" with them - the codes that would have made their voices audible (Moore 2011, 399). Admittedly, the public is often unwilling to listen to the stories of a vanquished army. Yet in Taiwan's former metropole Japan, many "brothers-in-arms associations" (senyūkai 戦友会) were created immediately after the war, in which veterans could gather and — as long as they kept a low profile—cultivate camaraderie or pray for the souls of their fallen comrades (Takahashi 2005). In Taiwan, the Kuomintang's policy of erasing the island's colonial past made this impossible. Returned veterans were thus forced into silence, and had to be content with informal relations we know little of. It was all the more frustrating that those stationed in China and in Taiwan had not been vanquished in the field: to them, defeat was a political notion, not a lived experience. Notwithstanding, they found themselves marginalized. Although to a lesser extent, this drastic devaluation of the subjectivities shaped during the war affected former members of paramilitary organizations too. Everything that smacked of Japanese militarism was suspect in the eyes of the new government, and now had to be kept silent.

Finally, this bleak and tense context spawned constant rumors that a return to armed conflict was imminent. As early as March 1946, the American Embassy in China informed Washington of "rumors that Formosan-Chinese know the disposition of hidden Japanese military supplies ..., and that these may be used in an uprising" (NARA RG84/UD2279/24). In January 1947, shortly before the February 28 Incident, the American consul in Taipei sent a worried telegram to his ambassador in Nanking, writing that Taiwan was "alive with rumors" of an impending war that would pit (in most versions) America against the USSR. People feared the island would be used as a base by the United States and would again be subject to aerial bombings. Another rumor announced "a return of the Japanese in force" to Taiwan, in some versions with the blessing of the Americans, who-it was said — deemed China unworthy of managing the island (NARA RG84/UD2279/72). It is not known where and how these rumors started. They are, nevertheless, enlightening about the general mood of which they were a symptom: the war, whoever its protagonists might be, was perceived as unfinished business. By the time the 1947 revolt exploded, Taiwan thus found itself in a paradoxical and dangerous situation. On the one hand, the conflict was still fresh in people's minds. On the other hand, the new regime silenced its memory and annulled its empowering effects for a large part of the youth, which it deeply distrusted. These were ideal conditions for a backlash and, during the February 28 Incident, the frustration caused by government corruption, economic crisis, and cultural contempt was expressed in forms bequeathed to the Taiwanese youth by wartime mobilization.

\section{The 1947 Revolt as Spontaneous Remobilization}

When demonstrations against police brutality evolved into an island-wide uprising in early March 1947, Taipei and Nanjing were quick to publicly blame the Communists for 
manipulating the masses. This is not to be wondered at, given that the Kuomintang was engaged in a civil war with Mao Zedong's forces on the mainland. In reality, this accusation was made in bad faith: the authorities knew that Communist influence in Taiwan was minor; for them, it was the island's Japanese heritage that really was the root of the evil.

This impression was due not only to the Japanese education of restive Taiwanese elite, but also to the participation of veterans in the uprising. Internal Chinese sources stressed their number and the leading role they played in armed action (NSHA 280-84). The authorities looked for explanations of this rebelliousness. One official report accused the Taipei Resolution Committee of gathering veterans to constitute an army and fight the Chinese troops (IMH 228/01/06/002). The head of military police in Taiwan, expressing the most widely shared point of view, maintained that these people had been "poisoned" by the education of the "Japanese bandits" (ZLXJ 187).

The experience of former soldiers was indeed perceived as an asset by some of the self-proclaimed leaders of the revolt. Most often, however, grassroots actors made the connection themselves: the rapid collapse of the police and the thinness of military forces in Taiwan in early 1947 provided a seemingly unique opportunity to recover the pride and sense of mission militarized young men had been able to experience during the war, and which they had so painfully lost thereafter. The repertoires of action and subjectivation formed during wartime were "remobilized" (Audoin-Rouzeau and Prochasson 2008; Horne 2009). Since this was done by the rebels' own initiative, I term this phenomenon "spontaneous remobilization."

Peer pressure was a crucial factor in this remobilization. Lin Qinglong recollected that his younger brother was "enrolled" on March 4 while going to work. "A guy who knew him saw him and said 'you are a Japanese soldier (ni shi Riben bing chushen de 你是日本兵出身的), what are you doing here? Go! We are all regrouping at the fountain!”' (Chang 1994a, 237 [1993]). This pressure could become oppressive, as it did for Tu Liutong:

At that time many people told me: "you're young, you were in the army, why don't you go and take part in the fight against the Chinese (canjia da Zhongguozi 參加打中國仔)?” My acquaintances, my neighbors, everybody was telling me the same thing. There was a lot of pressure and I couldn't take it anymore, but I knew that participating was pointless, so I ran away and hid for a week in a farm in Puzi. (Chang 1994a, 149 [1993])

As this case shows, war experience did not necessarily make people more bellicose. Some interviewees even justified their passivity by their first-hand knowledge of fighting: they were in a good position to know that armed action was hopeless. In many instances, nevertheless, being a former soldier of the Japanese army implied a duty to rebel, or at least to take up arms and maintain order in the streets vacated by the police (Chou 1997, 61 [1995]). This obligation was not only expressed by the peer group. In the Jiayi region, the radio station seized from the authorities "broadcast the names of [former] soldiers with ... the unit they belonged to, saying these people had to come as fast as possible because our brothers in arms were about to die" (Chang 1995, 113 [1994]). Former soldiers were often considered responsible for the safety of the community and of their "brothers in arms” (senyū, zhanyou 戰友, a recurrent term in the interviews). According to Lin Yujing, a former policeman in Xingang, 
... everyone was listening to the radio, which was saying in Japanese: "Those from this unit or that unit, go gather at the Jiayi station, or at the main gate of this public garden." Many people had been soldiers during the Japanese period, some of them had come back from the overseas battlefields not long before, so when they heard that they thought their units were being brought together again, they ran to enlist. (Chang 1995, 266 [1993])

Although Lin may have exaggerated his claim that former soldiers lived the revolt as the continuation of the war, this tendency is visible in both contemporary sources and oral history. Wen Lianzhang, a shopkeeper, depicted the uprising as a full-fledged call to arms: "We heard the radio say that all the people who had belonged to the Japanese army ... had to gather," because they "had received formal military training" (Chang 1995, 97 [1994]). Military organization and hierarchy were often imitated. In many places, rebels tried to reconstitute their units, or at least regroup along corps lines. For example, in the siege of the Huwei Airfield in central Taiwan, "Navy brigades" (kaigun tai 海軍隊) and “Army brigades" (rikugun tai 陸軍隊) were distinct entities (Chang 1994a, 32 [1993]). Some units took names inspired by local origins ("Attack Unit of Pingdong"), by the place they were sent during the war ("Returnees from Hainan Island") (IMH 228/01/06/002), or by paramilitary organizations of colonial times. The 2.28 Incident thus provoked a mushrooming of para- or pseudo-military groups-sometimes very poorly armed - referring directly to the wartime period.

Almost fifty years after the rebellion, and in spite of a collective memory that privileges victimhood over heroism, it is striking to see how prevalent martial vocabulary was in the testimonies: rebels were "waging war" (zuozhan 作戰) (Chang 1995, 266 [1993]; Ts'ai 2008, 91 [1995]) against Chinese soldiers. Wen Lianzhang used the term "front" to designate the location of the fighting. In the same tone, Tang Baofu, a Zou aborigine, remembered receiving a "combat order" requiring his presence on the "battlefield" (zhandi 戰地). In his recollection, the martial ethos replaced any kind of political consideration: “ $\ldots$ all we knew is that we had received a combat order... Why were we fighting? It wasn't very clear to us” (Chang 1994a, 61 [1993]).

This puzzling declaration signals an important fact: young rebels showed no loyalty to Japan as a polity. The model they claimed for themselves was the "Japanese soldier," not the Japanese tout court. In Benedict Anderson's words, the "political style" of Japanese militarism "was vulnerable to unexpected transformations": the values and aesthetics of "self-sacrifice, austerity, fraternity, and heroism," which had been exalted in a Japanese imperial framework, could be put to other uses after Tokyo's defeat (Anderson 1972, 33). For the Taiwanese youth, this use was less an articulate political project than an upsurge of anger and wounded dignity against a despised regime. This often put them at odds with older elites who used the circumstances to push their long-standing agenda of self-rule (jichi, zizhi 自治; Phillips 2003), but were mostly opposed to armed action and had little to no control over restive youngsters.

Former rebels, when interviewed decades later, were still enthusiastic about the qualities of Japanese soldiers. Remobilization of the Japanese-military repertoire visibly allowed them to re-experience some of the feelings of empowerment of war mobilization. With the former colonial overlord gone and the Chinese reinforcements yet to arrive, these young Taiwanese were the only heroes on the ground for several thrilling days. 
To explain his taking up arms, Li Jianghai said that his “Japanese spirit (Nihon seishin 日本 精神) was too strong [to contain]” (Chang 1995, 113 [1994]). Conversely, contempt for the mainland Chinese soldiers was unanimous. Their ragged appearance and poor discipline had already made a disastrous impression when they had first landed in late 1945. During the revolt, disparaging Japanese propaganda about them gained new currency, including the use of the derogatory term Shina hei 支那兵 (roughly translatable as “Chink soldier" in the wartime context) (Chang 1995, 266 [1993]). The martial ethos and aesthetics valued by the rebels were not alien to the Kuomintang, which had tried to promote them in China since before the war. Like many of its efforts at mobilizing society, however, this had been a relative failure. In Taiwan, as in most of East Asia, youthful militarism was still closely associated with Japan, and the spectacle of the ragtag, war-worn Chinese troops of 1945 did little to sever that connection. Shortly after the quelling of the rebellion, the mayor of Taipei identified this as a major factor of sedition in a speech to officers: "[the rebels said] a Japanese soldier could take thirty Chinese soldiers, that they didn't even need to fight since the Chinese would run away upon seeing a Japanese soldier..." (Xinshengbao 1947).

To be sure, there was a good deal of bravado in the rebels' martial tone, but this very fact hints at the feeling of empowerment that took hold of them. Tu Liutong gave a vivid account of the theatrical dimension of the revolt: returned soldiers wore Japanese uniforms and carried swords, "claiming to be officers, running all over the place, saying they wanted to tackle the Chinese ... but they had no ammunition for their rifles!" (Chang 1994a, 183 [1993]). Many officer titles were usurped. Sometimes, insignias were just traded: Huang Qingbiao lent his to a comrade in order to entitle him to lead the assault on a military airport (Chang 1995, 87 [1994]).

Spontaneous remobilization also allowed revirilization. The humiliation felt by young Taiwanese men after Japan's defeat had a sexual dimension, for what was perceived as the Chinese soldiers' predation of local women created intense resentment (Lai 1994, 22 23). In 1947, while the protagonists of armed action were almost invariably male, girls and young women also contributed, most often in neatly gendered roles such as preparing food, washing clothes for the "fighters" (Chang 1994a, 35 [1993]), or providing moral support. The Jiayi radio was partly taken over by female high-school students, who enjoined young men to fight and girls to support and feed them. They broadcast the popular Japanese military song "March of the Battleship," galvanizing the veterans (Chang 1995, 328 [1994]).

As demonstrated above, the militarization of Taiwan during the war was not limited to soldiers but percolated into society in general. The insurgency provided an opportunity to openly reconstitute the solidarities forged in youth and paramilitary organizations (Hsu 1995, 54 [1994]). Middle- and high-school students played a particularly active role, "eagerly joining" makeshift peace-maintaining units in Taipei, wearing armbands that "gave them a sense of authority" (Kerr 1965, 269). Schools had been equipped during wartime with practice weapons, such as wooden swords and training rifles, which were frequently used during the revolt (Chang 1995, 92 [1994]; Hsu 1995, 149 [1994]).

Wu Qingnian gave an instructive account of student mobilization in his city of Tainan. A former technician in the Air Force turned secondary school teacher, he learned about the revolt on March 1 through the radio. His young age (barely twenty-one), social status, and military record gave him legitimacy to mobilize his students. He led them in collecting rifles and swords still stored in the outskirts of the city. $\mathrm{Wu}$-thus promoted, or 
reverted, from teacher to soldier-organized street patrols to "maintain order" with vehicles "borrowed" from the police (Chang 1994a, 22-25 [1993]). In the southern city of Kaohsiung, High School No. 1 became the headquarters of the young rebels. In most testimonies, students appeared as the group most prone to show off their bravery in frequently suicidal operations. In Kaohsiung, for instance, a self-styled "Students' Army" of a dozen members charged the railway station with little more than swords and a few grenades, only to meet the machine-gun fire of the military police (Hsu 1995, 161 [1994]). We can only speculate about whether these youngsters were overcompensating for not being old enough to take part in the real war.

After reinforcements arrived from the mainland on March 9, it became obvious that acting out the war did not suffice. Worse still, this mimicry fueled mainland Chinese resentment. After eight years of savage Japanese invasion, the role-playing of the young Taiwanese rebels triggered an explosive mixture of anger and fear. It even led a section of the authorities to believe that actual Japanese soldiers were taking part in the uprising. The head of military intelligence in Taiwan asserted in an internal report that "after Japan's surrender, more than two thousand commando troops [had] stayed behind" in the mountains of eastern Taiwan, with many more scattered all over the island, waiting for an opportunity "to take Taiwan back." The uprising was believed to have provided such an opportunity (DAHB, 16-17). A similar fear had already been expressed in 1946 (NARA RG84/UD2279/24), revealing anxiety over persisting Japanese presence in Formosa, and, more generally, over the imperfection of China's military victory over Japan. In reality, however, Japanese participation in the uprising was nonexistent, and what the secret services feared were Japanese troops were actually Taiwanese clothed in Japanese uniforms.

Mainland Chinese soldiers did not stop at such subtleties. Leaving aside the targeted killing of Taiwanese elites, the quelling focused on young males, who were often shot on sight. Veterans of the Imperial Army were the most exposed group and fled in disarray, whether they had actually been involved or not (Chang 1994b, 148 [1993]). The material symbols of Japanese-military identity, so prized during the rebellion, suddenly became a deadly liability; for example, the possession of a Japanese sword was sometimes considered solid proof of guilt. Those who could made them disappear by burning their uniforms and wartime photographs, or by burying their weapons like Wu Qingnian and his students (Chang 1994a, 40 [1993]). Wen Lianzhang fled to the mountains, while his father burnt his Japanese books and buried his swords (Chang 1995, 116 [1994]). Many others did the same. The Taiwanese soldiers of the Imperial Army had suffered their last defeat.

\section{ConcLusion}

The February 28 Incident was profoundly shaped by Japan's mobilization and militarization of Taiwanese youth during the war. This mobilization, although coercive, had for many young male Taiwanese marked an improvement over their previous colonial status. After retrocession to China, the island's troubled conditions kept the memory of war vivid, while anger built up against the corrupt and inefficient Chinese authorities. When the crisis erupted in 1947, the "Japanese-military repertoire" was remobilized by 
many rebels for the skills and the confidence it provided them, emboldening them to take ultimately suicidal action. This role-playing was bound to be misinterpreted by Chinese Nationalists as nostalgia for Japanese rule.

After the revolt was crushed, the language and symbols bequeathed by wartime became anathema, and the authorities made sure that the island's militarized youth were kept in check or absorbed in the Chinese army. Meanwhile, the political atmosphere changed with the Kuomintang's defeat by the Communists in 1949. The aftermath of World War II faded into the Cold War; for Chiang Kai-shek's government, which took refuge in Taipei, the Red Scare entirely replaced the Japanese nemesis. Only with the end of the Cold War, worsening nationalist tensions in East Asia, and identity politics in Taiwan did the question of the island's role in Japan's war effort become contentious again.

This study of the February 28 Incident could have broader implications. Measures of mobilization and militarization comparable to those taken in Taiwan were also adopted in colonial Korea and in occupied territories such as Java or, to a lesser extent, Indochina. Although these policies were of variable durations and consequences, existing literature hints at the popularity of the Japanese military style among male youth (Anderson 1972; Mark 2003; Marr 1995). Mutatis mutandis, postwar "spontaneous remobilization," does not seem to have been unique to Taiwan either. After their defeat, the Japanese left in their wake a generation of militarized Asian youth who had crystalized "a powerful selfconsciousness" (Anderson 1972, 1), and played an important part in events such as the Javanese independence movement or the violent unrest that afflicted Korea. The causes they espoused varied from national liberation to communism to more ill-defined expressions of discontent, but their style and vocabulary were often similar to that of the 1947 Taiwanese rebellion (Cumings 1981, 68-81). Spontaneous remobilization thus seems to have concerned a generation of young Asians in the wake of Japan's wartime empire. Future research on this phenomenon could enrich our understanding of the grassroots conflicts that affected the region in the aftermath of World War II, before newly formed states and the Cold War superimposed their logic on them.

\section{Acknowledgments}

This research was supported by Sciences Po and the Yale Fox International Fellowship. I would like to thank the Taipei 2.28 Memorial Museum and an anonymous reviewer.

\section{List of References}

Anderson, Benedict. 1972. Java in a Time of Revolution: Occupation and Resistance, 1944-1946. Ithaca, N.Y.: Cornell University Press.

Audoin-Rouzeau, Stéphane, and Annette Becker. [2000] 2003. 14-18: Understanding the Great War. Translated by Catherine Temerson. New York: Hill \& Wang.

Audoin-Rouzeau, Stéphane, and Christophe Prochasson. 2008. "Introduction." In Sortir de la Grande Guerre: Le monde et l'après-1918 [Coming out of the Great 
War: The world after 1918], eds. Stéphane Audoin-Rouzeau and Christophe Prochasson, 13-19. Paris: Tallandier.

Bayart, Jean-François. [2004] 2007. Global Subjects: A Political Critique of Globalisation. Translated by Andrew Brown. Cambridge: Polity.

— . 2008. "Hégémonie et coercition en Afrique subsaharienne: Politique de la chicotte" [Hegemony and coercion in sub-Saharan Africa: Politics of the whip]. Politique Africaine 110(2):123-52.

Cabanes, Bruno, and Guillaume Piketty. 2007. "Sortir de la guerre: Jalons pour une histoire en chantier" [Coming out of war: Milestones for a history in progress]. Histoire@Politique 3.

Chang Yen-Hsien, ed. 2006. Er'erba shijian zeren guishu yanjiu baogao [Research report on responsibilities in the 2.28 Incident]. Taipei: Memorial Foundation of the 2.28 Incident.

Chatani, Sayaka. 2014. "Nation-Empire: Rural Youth Mobilization in Japan, Taiwan, and Korea 1895-1945.” PhD diss., Columbia University.

Chen Tsui-Lien. 2002. “Qu zhimin yu zai zhimin de duikang: Yi 1946 nian ‘Taiwan nuhua’ lunzhan wei jiaodian" [Decolonization against recolonization: Focusing on the 1946 debate about the "enslavement of Taiwan"]. Taiwan shi yanjiu 9(2):145-201.

Chen Wensong. 2015. Zhimin tongzhi yu qingnian: Taiwan zongdufu de qingnian jiaoyu zhengce [Colonial rule and youth: The youth education policy of the Taiwan Government-General]. Taipei: National Taiwan University Press.

Chi Chia-Lin. 2007. Taiwan Er'erba da jiemi [The 2.28 in Taiwan exposed]. Taipei: Haixia.

Ching, Leo. 2001. Becoming "Japanese": Colonial Taiwan and the Politics of Identity Formation. Berkeley: University of California Press.

Chou Wan-YaO. 1996. “The Kôminka Movement in Taiwan and Korea: Comparisons and Interpretations.” In The Japanese Wartime Empire, 1931-1945, eds. Peter Duus, Ramon Myers, and Mark Peattie, 40-70. Princeton, N.J.: Princeton University Press.

Cumings, Bruce. 1981. The Origins of the Korean War, Vol. 1: Liberation and the Emergence of Separate Regimes, 1945-1947. Princeton, N.J.: Princeton University Press.

Descamps, Florence. 2001. L'historien, l'archiviste et le magnétophone: De la constitution de la source orale à son exploitation [The historian, the archivist and the tape recorder: Creating and using oral sources]. Paris: CHEFF.

Fix, Douglas. 2006. "Reading the Numbers: Ethnicity, Violence and Wartime Mobilization in Colonial Taiwan." In Taiwan under Japanese Colonial Rule, 1895-1945, eds. Ping-Hui Liao and Der-Wei David Wang, 327-58. New York: Columbia University Press.

Forgacs, David, and Eric Hobsbawm, eds. 2000. The Antonio Gramsci Reader: Selected Writings 1916-1935. New York: New York University Press.

Foucault, Michel. [1984] 1990. The History of Sexuality, Vol. 2: The Use of Pleasure. Translated by Robert Hurley. New York: Vintage Books.

Fujitani, Takashi. 2000. "The Masculinist Bonds of Nation and Empire: The Discourse on Korean 'Japanese' Soldiers in the Asia Pacific War." Senri Ethnological Studies 51:133-61.

- 2011. Race for Empire: Koreans as Japanese and Japanese as Americans during World War II. Berkeley: University of California Press.

Horne, John. 2009. "Demobilizing the Mind: France and the Legacy of the Great War, 1919-1939." French History and Civilization 2:101-19. 
Kerr, George. 1965. Formosa Betrayed. Boston: Houghton Mifflin.

Kondō Masami. 1996. Sōryokusen to Taiwan: Nihon shokuminchi hōkai no kenkyū [Total war and Taiwan: A study of the collapse of a Japanese colony]. Tokyo: Tosui shobo.

Kushner, Barak. 2010. "Pawns of Empire: Postwar Taiwan, Japan and the Dilemma of War Crimes." Japanese Studies 30(1):111-33.

LaI Tse-Han, ed. 1994. Er'erba shijian yanjiu baogao [Research report on the 2.28 Incident]. Taipei: Shibao.

Lai Tse-Han, Ramon H. Myers, and Wei Wou. 1991. A Tragic Beginning: The Taiwan Uprising of February 28, 1947. Stanford, Calif.: Stanford University Press.

Lin Jiwen. 1996. Riben ju Tai moqi (1930-1945): Zhanzheng dongyuan tixi zhi yanjiu [The late period of Japanese occupation in Taiwan (1930-1945): A study of the war mobilization system]. Taipei: Daoxiang.

Mark Ethan. 2003. "Appealing to Asia: Nation, Culture, and the Problem of Imperial Modernity in Japanese-Occupied Java, 1942-1945.” PhD diss., Columbia University.

MARR, DAVID. 1995. Vietnam 1945: The Quest for Power. Berkeley: University of California Press.

Moore, Aaron. 2011. "The Problem of Changing Language Communities: Veterans and Memory Writing in China, Taiwan, and Japan." Modern Asian Studies 45(2): 399-429.

Phillips, Steven. 2003. Between Assimilation and Independence: The Taiwanese Encounter Nationalist China, 1945-1950. Stanford, Calif.: Stanford University Press.

TAkAhashi, SABurō, ed. 2005. Kyōdō kenkyū: Senyūkai [Collective research: The veterans associations]. Tokyo: Inpakuto.

TAng XIYOng. 2005. "Tuoli kunjing: zhanhou chuqi Hainan dao zhi Taiwanren de fan Tai” [Out of predicament: The repatriation of the Taiwanese from Hainan island in the early postwar period]. Taiwan shi yanjiu 12(2):167-208.

TomiYama Ichirō. 2005. “On Becoming 'a Japanese’: The Community of Oblivion and Memories of the Battlefield.” Asia-Pacific Journal: Japan Focus 3(10).

Ts'ai, Hui-Yu Caroline. 2009. Taiwan in Japan's Empire Building: An Institutional Approach to Colonial Engineering. New York: Routledge.

Xinshengbao [New Life Daily]. 1947. May 8.

Xu Zhaorong. 1995. Taiji laobing de xue lei hen [The bitter tears of Taiwanese veterans]. Taipei: Qianwei.

\section{Archives}

DAHB (ER'ERBA SHIJIAN DANG'AN HUIBIAN [COLLECTED DOCUMENTS ON THE 2.28 INCIDENT]). 2002. Vol. 16. Chang Yen-hsien, ed. Taipei: Academia Historica.

GK (George Kerr's Papers). Taipei 2.28 Memorial Museum.

IMH (Archives of the Institute of Modern History). Academia Sinica, Taipei.

NARA (National Archives and Records Administration). Washington, D.C.

NSHA (NANJING DI'ER LISHI DANG'AN GUAN CANG ER'ERBA SHIJIAN DANG'AN SHILIAO [ARCHIVAL documents about the 2.28 Incident stored in the Nanjing Second Historical Archives]). 1992. Vol. 1. Chen Xingtang, ed. Taipei: Renjian.

ZLXJ (ER'ERBA SHIJIAN ZILIAO XUANJI [SELECTED DOCUMENTS ON THE 2.28 INCIDENT]). 1993. Vol. 4. Taipei: Academia Sinica. 


\section{Oral Histories}

Chang Yen-Hsien, ed. 1994a. Jiayi beihui Er'erba [The 2.28 Incident in the Jiayi region, vol. 1]. Taipei: Wu Sanlian Foundation.

. 1994b. Jilong yugang Er'erba [The 2.28 Incident in the Jilong region]. Taipei: Wu Sanlian Foundation.

1995. Jiayun pingye Er'erba [The 2.28 Incident in the Jiayi region, vol. 2]. Taipei: $\mathrm{Wu}$ Sanlian Foundation.

Сhou WAN-YAO, ed. 1997. Taiji Riben bing zuotanhui jilu bing xiangguan ziliao [Minutes of the symposium on the Taiwanese soldiers of the Japanese army, and related documents]. Taipei: Academia Sinica.

Hsu Hsuen-Chi. 1995. Gaoxiong shi Er'erba xiangguan renwu fangwen jilu [The 2.28 Incident in Kaohsiung]. Vol. 1. Taipei: Academia Sinica.

Ts'a Hur-Yu, ed. 2008. Zou guo liang ge shidai de ren: Taiwan Riben bing [The lives and times of Taiwanese veterans: Institute of Taiwan History]. Taipei: Academia Sinica. 